\title{
Influence of the weaning diet on the changes of glucose metabolism and of insulin sensitivity
}

\author{
BY JEAN GIRARD ${ }^{1}$, TARIK ISSAD ${ }^{2}$, JOCELYNE MAURY ${ }^{1}$, \\ FABIENNE FOUFELLE ${ }^{2}$, CATHERINE POSTIC ${ }^{1}$, ARMELLE \\ LETURQUE ${ }^{1}$ AND PASCAL FERRE 2 \\ ${ }^{1}$ Centre de Recherche sur l'Endocrinologie Moléculaire et le Développement, CNRS, 9 rue Jules \\ Hetzel, 92190 Meudon-Bellevue, France \\ ${ }^{2}$ Unité 342 INSERM, Hôpital Saint Vincent de Paul, 75014 Paris, France
}

In the rat, the suckling-weaning transition is attended by marked changes of nutrition (Henning, 1981; Girard et al. 1992). During the suckling period and until $15 \mathrm{~d}$ of age, milk (a diet poor in carbohydrate and rich in fat) constitutes the only source of nutrients for the newborn rat. Then, the newborn rat begins to nibble the laboratory chow provided to the mother (a diet rich in carbohydrate and poor in fat) and the amount of milk ingested progressively decreases. Between 28 and $30 \mathrm{~d}$ after birth, weaning is achieved and the newborn rats are fed with the laboratory chow, i.e. a high-carbohydrate low-fat diet. These nutritional changes are associated with large modifications in the concentration of circulating hormones which are important for the regulation of glucose metabolism. The suckling period in the rat is characterized by high plasma glucagon and low plasma insulin levels (Girard et al. 1977). When the rats are spontaneously weaned onto the laboratory chow, plasma glucagon progressively decreases and plasma insulin progressively increases (Girard et al. 1977). The increase in plasma insulin and the decrease in plasma glucagon are faster and larger when the rats are abruptly weaned to a high-carbohydrate low-fat diet at $20 \mathrm{~d}$ (Perdereau et al. 1990). In contrast, abrupt weaning onto a high-fat low-carbohydrate diet prevents the changes in plasma insulin and glucagon (Perdereau et al. 1990). It is obvious that the changes in hormonal pattern account for a large part of the metabolic adaptations observed during the sucklingweaning transition. In suckling rats, glucose tolerance in response to intraperitoneal glucose injection is decreased (Tsujikawa \& Kimura, 1981) and a residual glucose production persists during intravenous glucose infusion (Ferré et al. 1985). These variables are normalized after weaning onto a high-carbohydrate diet (Tsujikawa \& Kimura, 1981; Ferré et al. 1985). This suggests that a state of insulin resistance is present during the suckling period which rapidly disappears after weaning onto a highcarbohydrate diet. The aim of the present paper is to review the factors contributing to the changes of tissue insulin sensitivity during the suckling-weaning transition.

\section{QUANTIFICATION OF CHANGES IN INSULIN SENSITIVITY DURING THE SUCKLING-WEANING TRANSITION}

Glucose metabolism and insulin sensitivity have been studied in 15-d-old suckling rats and in 30-d-old rats weaned at $21 \mathrm{~d}$ onto a high-carbohydrate low-fat diet ( $\mathrm{HC} ; \mathrm{g} / \mathrm{kg}: 600$ carbohydrate, 250 protein, 50 fat, 50 cellulose, 50 minerals) or onto a high-fat carbohydrate-free diet (HF; g/kg: 430 fat, 370 protein, 150 cellulose, 50 minerals), by using radioactive glucose and the euglycaemic hyperinsulinaemic clamp (Issad et al. 1987, 1988). 
In the basal state, the blood glucose concentration was slightly higher in HF-weaned rats $(1240 \mathrm{mg} / \mathrm{l})$ than in suckling or $\mathrm{HC}$-weaned rats $(1050 \mathrm{mg} / \mathrm{l})$, but their rates of glucose turnover were similar: $14 \mathrm{mg} / \mathrm{min}$ per $\mathrm{kg}$ in suckling and $\mathrm{HC}$-weaned rats and 13 $\mathrm{mg} / \mathrm{min}$ per $\mathrm{kg}$ in HF-weaned rats (Issad et al. 1987, 1988). This confirms previous findings showing that the glucose turnover rate was 1.5- to 2-fold higher in suckling and HC-weaned rats than in postabsorptive adult rats (Snell \& Walker, 1973). Plasma insulin concentration was higher in HC-weaned rats than in HF-weaned and suckling rats: $50 v$. respectively 30 and $20 \mu \mathrm{U} / \mathrm{ml}$ (Issad et al. 1987, 1988).

During the euglycaemic clamp, plasma insulin concentration rose to 370 and 350 $\mu \mathrm{U} / \mathrm{ml}$ in $\mathrm{HC}$ - and HF-weaned rats respectively, but increased to $900 \mu \mathrm{U} / \mathrm{ml}$ in suckling rats despite similar insulin infusion rates, indicating a decreased insulin clearance in suckling rats. Hepatic glucose production was totally suppressed in HC-weaned rats whereas it remained at $40 \%$ of its basal value in suckling and in HF-weaned rats. The increase in glucose utilization was much higher in HC-weaned rats than in suckling rats. Thus, a state of insulin resistance was present in the liver and insulin-sensitive tissues of suckling rats; this disappeared after weaning onto a high-carbohydrate diet, but not after weaning onto a high-fat diet (Issad et al. 1987, 1988).

Hepatic insulin resistance during the suckling period or after weaning onto a high-fat diet is probably due to a post-receptor defect in insulin action since insulin receptor number and tyrosine kinase (EC 2.7.1.112) activity did not change during the sucklingweaning transition (Blazquez et al. 1976; Shinha \& Jenquin, 1987; Margolis et al. 1990). The high levels of plasma glucagon which prevail during the suckling period or after weaning onto a high-fat diet (Beaudry et al. 1977; Girard et al. 1977; Issad et al. 1988) could also exert anti-insulin effects on hepatic glucose production. Hepatic glycogen content remains very low during the suckling period and increases only after weaning onto a high-carbohydrate diet (Snell \& Walker, 1973). Thus, hepatic glucose production during the suckling period and after weaning onto a high-fat diet is essentially derived from gluconeogenesis (Beaudry et al. 1977; Ferré et al. 1977, 1985; Decaux et al. 1986), whereas hepatic glucose production after weaning onto a high-carbohydrate diet is essentially derived from glycogenolysis (Snell \& Walker, 1973). The fact that gluconeogenesis is less sensitive than glycogenolysis to insulin inhibition (Chiasson et al. 1976) could also account for the persistence of a residual glucose production during hyperinsulinaemia in the suckling and HF-weaned rats.

The use of euglycaemic hyperinsulinaemic clamp coupled with injection of radioactive 2-deoxyglucose has shown that stimulation of glucose utilization by insulin was markedly decreased in skeletal muscles and white adipose tissue of suckling rats. After weaning onto a high-carbohydrate diet, skeletal muscles and adipose tissue became very sensitive to insulin action. The increase in insulin sensitivity that occurred at weaning was linked to the dietary transition from a high-fat to a high-carbohydrate diet, since skeletal muscles and adipose tissue of rats weaned onto a high-fat diet remained insulin-resistant (Issad et al. 1988). The mechanisms responsible for muscle insulin resistance have not been determined but could involve a defect in: (1) insulin receptors function, (2) glucose transport, or (3) enzymes catalysing different steps of glucose metabolism. Muscle insulin resistance during the suckling period is probably due to a post-receptor defect in insulin action since insulin receptor number and tyrosine kinase activity are higher in the suckling than in the HC-weaned rats (Wang, 1985; Alexandrides et al. 1989). The increase in insulin responsive (GLUT-4) glucose transporter mRNA and protein levels 

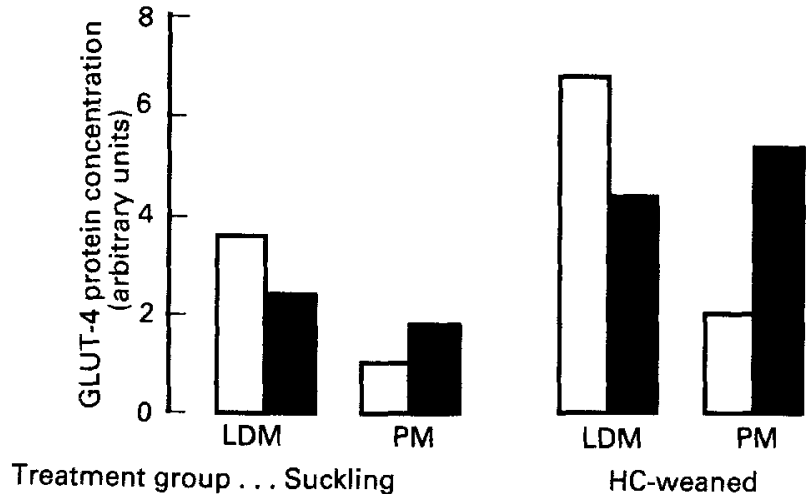

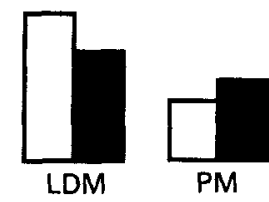

HF-weaned

Fig. 1. Insulin effect on translocation of glucose transporter GLUT-4 from the low-density microsomes (LDM) to plasma membranes (PM) in isolated rat adipocytes. Suckling rats were $15 \mathrm{~d}$ old, high carbohydrate low-fat (HC)-weaned and high-fat carbohydrate-free (HF)-weaned rats were $30 \mathrm{~d}$ old and were weaned at day 21 . GLUT-4 concentration was determined by scanning densitometry of western blots performed with a specific antibody against GLUT-4. ( $\square$ ), In the absence of insulin; ( $\square$ ), in the presence of insulin. Redrawn from Leturque et al. (1991).

that occur after weaning onto a HC diet could play an important role in the increased sensitivity of muscle to insulin (Leturque et al. 1991).

\section{INSULIN SENSITIVITY OF ISOLATED ADIPOCYTES DURING THE SUCKLING- WEANING TRANSITION}

The mechanisms responsible for the changes of insulin sensitivity in white adipose tissue during the suckling-weaning transition have been investigated in vitro using isolated adipocytes (Issad et al. 1989). Insulin binding to isolated adipocytes and tyrosine kinase activity of purified insulin receptors were higher in suckling rats than in HF-weaned and HC-weaned rats (Issad et al. 1989; Maury et al. 1992a). In contrast, insulin-stimulated glucose transport was markedly reduced in adipocytes from suckling and HF-weaned rats compared with those from HC-weaned rats (Issad et al. 1989; Leturque et al. 1991). As the translocation of glucose transporters from the intracellular membranes to the plasma membrane was not affected (Fig. 1), the decreased glucose transport in adipocytes from suckling rats was due to a reduced number of intracellular insulin-responsive glucose transporters (GLUT-4; Leturque et al. 1991). Moreover, total glucose metabolism was increased 3-fold by insulin in adipocytes from $\mathrm{HC}$-weaned rats, whereas glucose metabolism was totally unresponsive to insulin in adipocytes from suckling or HFweaned rats (Fig. 2; Issad et al. 1989). The increased glucose utilization in response to insulin in adipocytes from HC-weaned rats was essentially due to a stimulation of lipogenesis (Fig. 1; Issad et al. 1989). This suggested that insulin resistance in adipose tissue of suckling and HF-weaned rats results from a very low capacity for lipogenesis (Tsujikawa \& Kimura, 1980; Issad et al. 1989). This has been confirmed by experiments in which lipogenesis was acutely $(2 \mathrm{~h})$ inhibited by 5-(tetradecyloxy)-2-furoic acid (TOFA; an inhibitor of acetyl-CoA carboxylase; EC 6.4.1.2; McCune \& Harris, 1979) in 

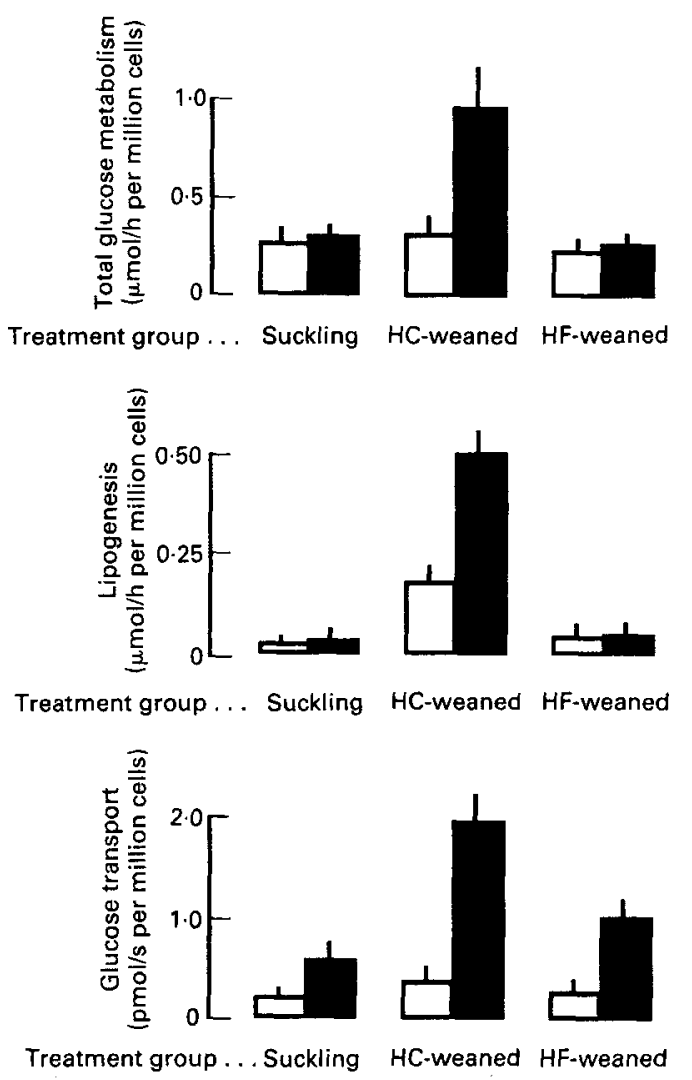

Fig. 2. Effects of insulin on glucose transport and glucose metabolism in isolated adipocytes of suckling, high-carbohydrate low-fat (HC)-weaned and high-fat carbohydrate-free (HF)-weaned rats. For measurement of glucose transport, adipocytes were incubated for $20 \mathrm{~s}$ in $50 \mu \mathrm{M}-\left[\mathrm{U}-{ }^{14} \mathrm{C}\right] \mathrm{glucose}$ in the presence or absence of insulin $(800 \mu \mathrm{U} / \mathrm{ml})$ and cell-associated radioactivity was determined. For measurement of glucose metabolism, adipocytes were incubated for $2 \mathrm{~h}$ in $5 \mathrm{mmol} / 1$ [ $\mathrm{U}^{-14} \mathrm{C}$ ]glucose in the presence or absence of insulin ( 800 $\mu \mathrm{U} / \mathrm{ml}$ ). Values are means with their standard errors represented by vertical bars for four to six determinations. Total glucose metabolism represents the incorporation of $\left[\mathrm{U}-{ }^{14} \mathrm{C}\right]$ glucose into $\mathrm{CO}_{2}$, glycerol, lactate and fatty acids. Lipogenesis represents the incorporation of $\left[\mathrm{U}-{ }^{14} \mathrm{C}\right] \mathrm{glucose}$ into $\mathrm{CO}_{2}$ and fatty acids. ( $\square$ ), In the absence of insulin; ( $\mathbf{\square})$, in the presence of insulin. Redrawn from Issad et al. (1988).

adipocytes of $\mathrm{HC}$-weaned rats. TOFA did not decrease glucose transport, but it markedly decreased the rate of glucose utilization in response to insulin, and induced a state of insulin resistance (Fig. 3) similar to the one observed in suckling or HF-weaned rats (see Fig. 2).

The low rate of lipogenesis during the suckling period, its large increase at weaning onto a $\mathrm{HC}$ diet and its maintenance at a low level after weaning onto a $\mathrm{HF}$ diet, resulted from parallel changes in the activity of pyruvate dehydrogenase complex (PDH) composed of three catalytic proteins: pyruvate decarboxylase (subunits $\mathrm{E}_{1} \alpha$ and $\mathrm{E}_{1} \beta ; E C$ 1.2.4.1), dihydrolipoamide acetyltransferase (subunit $\mathrm{E}_{2} ; E C$ 2.3.1.12) and dihydrolipoamide dehydrogenase (subunit $\mathrm{E}_{3} ; E C$ 1.8.1.4), fatty acid synthase ( $E C$ 2.3.1.85), acetyl-CoA carboxylase and ATP-citrate lyase (EC 4.1.3.8; Hahn, 1970; Tsujikawa \& Kimura, 1980; Gandemer et al. 1982; Coupé et al. 1990; Issad et al. 1989; Perdereau et al. 1992). It has been shown that the low activity of acetyl-CoA carboxylase, fatty acid 

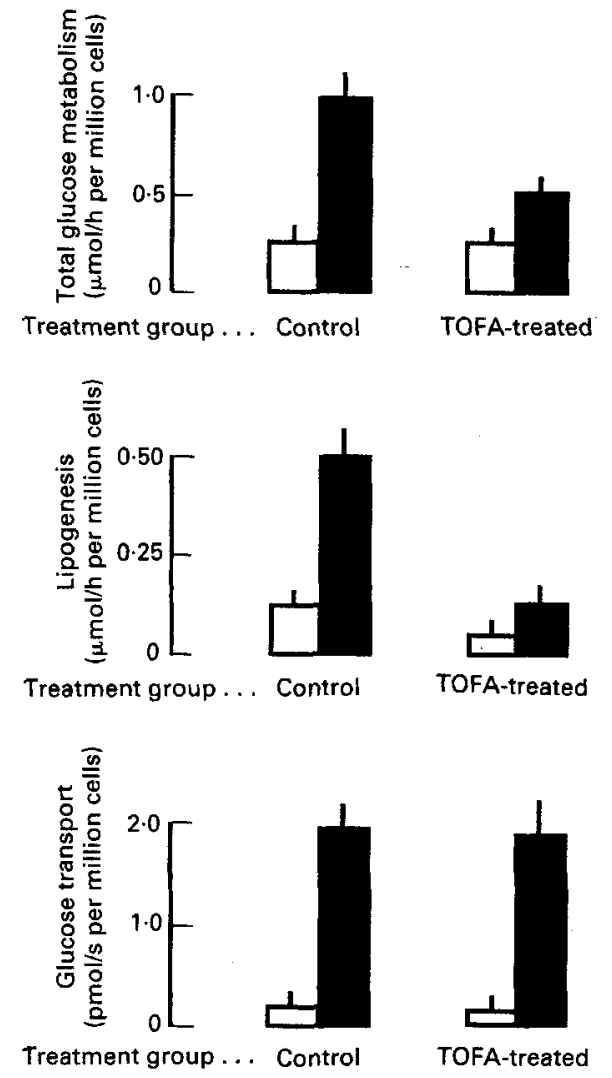

Fig. 3. Effects of an acute inhibition of lipogenesis by tetradecyloxyfuroic acid (TOFA) on the effect of insulin on glucose transport and glucose metabolism in isolated adipocytes of 30 -d-old rats weaned at $21 \mathrm{~d}$ onto a high-carbohydrate low-fat diet. For measurement of glucose transport, adipocytes were incubated for $5 \mathrm{~s}$ with ${ }^{14} \mathrm{C}$-labelled 3-O-methylglucose $(100 \mu \mathrm{M})$ in the presence or absence of insulin $(800 \mu \mathrm{U} / \mathrm{ml})$. Adipocytes were pre-incubated for $30 \mathrm{~min}$ in the absence or in the presence of TOFA $(100 \mu \mathrm{M})$. For measurement of glucose metabolism adipocytes were incubated for $2 \mathrm{~h}$ in $\left.5 \mathrm{mmol} / \mathrm{[U}-{ }^{14} \mathrm{C}\right]$ glucose in the presence or absence of insulin $(800 \mu \mathrm{U} / \mathrm{ml})$. Values are means with their standard errors for four to six determinations. Total glucose metabolism represents the incorporation of $\left[\mathrm{U}-{ }^{14} \mathrm{C}\right]$ glucose into $\mathrm{CO}_{2}$, glycerol, lactate and fatty acids. Lipogenesis represents the incorporation of $\left[\mathrm{U}^{14} \mathrm{C}\right]$ glucose into $\mathrm{CO}_{2}$ and fatty acids. ( $\square$ ), In the absence of insulin; ( $\mathbf{E})$, in the presence of insulin.

synthase and ATP-citrate lyase in adipocytes from suckling and HF-weaned rats and their high activity after weaning onto a $\mathrm{HC}$ diet were due to changes in the concentration of mRNA coding for these enzymes (Coupé et al. 1990; Perdereau et al. 1992). Similarly, the low activity of the PDH complex in adipocytes from suckling and $\mathrm{HF}$-weaned rats and its high activity after weaning onto a $\mathrm{HC}$ diet were due to changes in the concentration of mRNA coding for $E_{1} \alpha$ subunit of the PDH complex, the other subunit being less affected (Maury et al. 1992b). The rapid (2-4 h) and large (10-20-fold) increase in the concentration of mRNA coding for acetyl-CoA carboxylase and fatty acid synthase in adipose tissue of suckling rats receiving oral carbohydrate, suggests a regulation of the expression of these genes at the transcriptional level (Coupé et al. 1990; Maury et al. 1992b; Perdereau et al. 1992). As hyperinsulinaemia alone (euglycaemic hyperinsulinaemic clamp) did nöt reproduce the effects of oral glucose administration 
(hyperglycaemia and hyperinsulinaemia) in suckling rats, this suggested that insulin and glucose must act synergistically to increase lipogenic enzyme gene expression in white adipose tissue (Coupé et al. 1990).

\section{FACTORS RESPONSIBLE FOR THE DEVELOPMENT OF INSULIN SENSITIVITY OF ADIPOSE TISSUE AFTER WEANING ONTO A HIGH-CARBOHYDRATE DIET}

The fact that the insulin resistance of white adipose tissue observed during the suckling period is maintained after weaning onto a HF diet supports the view that the development of insulin sensitivity after weaning onto a $\mathrm{HC}$ diet is due to the switch from a high-fat to a high-carbohydrate diet. The consumption of a diet rich in carbohydrate after weaning induces large variations in blood glucose and plasma insulin concentrations after every meal (Coupé et al. 1990). This is particularly striking immediately after weaning, when the pups are still insulin-resistant. It might be hypothesized that large variations in blood glucose and plasma insulin levels could induce the synthesis of proteins involved in short-term insulin action such as: glucose transporters (Leturque et al. 1991) and lipogenic enzymes (Coupé et al. 1990), leading to an increased capacity for overall glucose metabolism. In keeping with this, we have recently studied rats weaned onto a $\mathrm{HC}$ diet containing acarbose, an inhibitor of intestinal $\alpha$-glucosidases (Maury et al. 1993). In rats weaned onto a HC diet containing acarbose, the postprandial changes in blood glucose and plasma insulin were markedly blunted (Maury et al. 1993). The increase in lipogenic enzyme activity was reduced by $50 \%$ and insulin sensitivity of isolated adipocytes was markedly lowered (Maury et al. 1993). This suggests that the prandial fluctuations in blood glucose and plasma insulin (and not their absolute concentrations) were important for stimulation of specific gene transcription. This has been recently confirmed by in vitro experiments. Explants from adipose tissue of 19-d-old suckling rats were cultured 6-24 h in a serum-free minimal essential medium (Foufelle et al. 1992). A large accumulation of fatty acid synthase (FAS) and acetyl-CoA carboxylase mRNA was observed in explants of adipose tissue cultured in the presence of insulin $\left(10^{-7} \mathrm{M}\right)$ and glucose $(5 \mathrm{~mm})$. Insulin did not induce FAS and acetyl-CoA carboxylase mRNA accumulation when the culture medium was deprived of glucose, but the effects of insulin on FAS and acetyl-CoA carboxylase mRNA levels were markedly potentiated when the glucose concentration in the medium was increased to 10 and 20 mM (Fig. 4; Foufelle et al. 1992). The effects of glucose and insulin on FAS and acetyl-CoA carboxylase mRNA levels were antagonized by dexamethasone, glucagon and isoproterenol and were potentiated by thyroid hormones (F. Foufelle, P. Ferré and $\mathrm{J}$. Gérard, unpublished results). Thus, insulin and glucose are the main factors involved in the initial induction of FAS and acetyl-CoA carboxylase mRNA in white adipose tissue.

\section{CONCLUDING REMARKS}

A marked increase in liver, muscle and adipose tissue sensitivity to insulin occurs after weaning onto a high-carbohydrate diet in the rat. The cellular and molecular mechanisms involved in this process have been studied in a series of in vivo and in vitro experiments on white adipose tissue. These experiments strongly support the view that the increase in insulin-regulatable glucose transporter (GLUT-4) and lipogenic enzyme mRNA concen- 

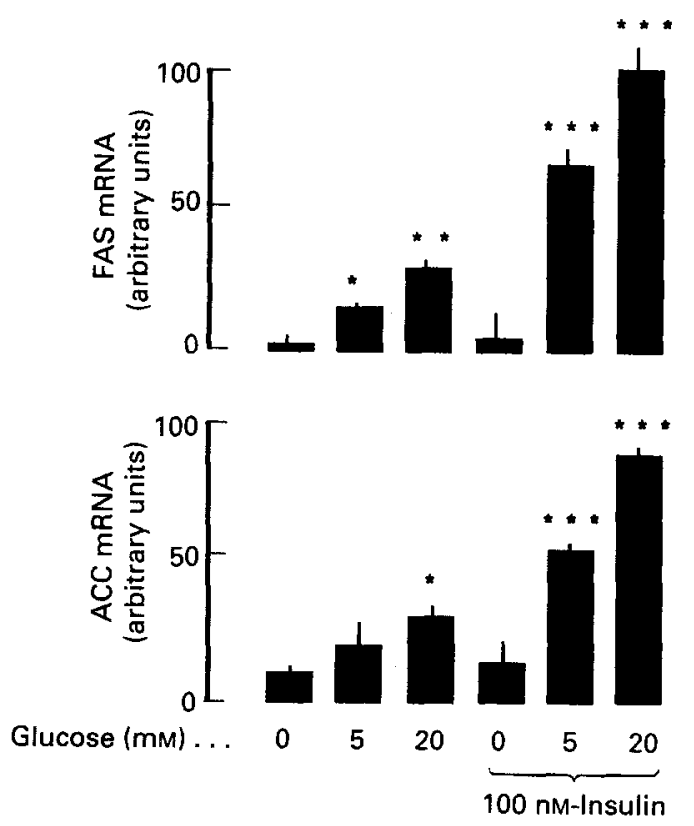

Fig. 4. Effect of glucose and insulin on fatty acid synthase ( $E C$ 2.3.1.85; FAS) and acetyl-CoA carboxylase (EC 6.4.1.2; ACC) mRNA concentrations in cultured adipose tissue from 19-d-old suckling rats. Adipose tissue was cultured in serum-free minimal essential medium for $6 \mathrm{~h}$ under various conditions. Results are expressed in arbitrary densitometric units as the mean of three independent experiments. Mean values were significantly different from values obtained in the absence of glucose ( $10 \mathrm{~mm}$-lactate and $1 \mathrm{mM}$-pyruvate being present as oxidative substrates): ${ }^{*} P<0 \cdot 05,{ }^{* *} P<0 \cdot 01,{ }^{* * *} P<0 \cdot 001$. Redrawn from Foufelle et al. 1992.

trations and activities that occur in white adipose tissue after weaning onto a $\mathrm{HC}$ diet is dependent on increased variations in plasma insulin and glucose concentrations. An increased glucose metabolism in white adipose tissue is necessary for the expression of insulin effects on lipogenic enzyme mRNA accumulation, since insulin is ineffective in vitro in the absence of glucose. It has been suggested that glucose-6-phosphate could play an important role in the effect of insulin on lipogenic enzyme gene expression in white adipose tissue (Foufelle et al. 1992). Other hormones and substrates could also play a role in the surge of lipogenesis after weaning. The fall in plasma glucagon after weaning onto a $\mathrm{HC}$ diet could reinforce the insulin-induced accumulation of lipogenic enzyme mRNA since this hormone strongly inhibits lipogenic enzyme gene expression in white adipose tissue (F. Foufelle, P. Ferré and J. Girard, unpublished results). The decrease in the dietary supply of fat and the fall in plasma unesterified fatty acid after weaning onto a HC diet could also potentiate the accumulation of lipogenic enzyme mRNA since long-chain fatty acids and particularly polyunsaturated fatty acids are potent inhibitors of lipogenic enzyme gene expression (Clarke et al. 1990).

This work was supported in part by grants from INSERM (CRE no. 87-4004), Ministère de la Recherche et de la Technologie (nos. 88-G-0119 and 90-G-0292) Bayer-Pharma France and Fondation pour la Recherche Médicale. We thank Danielle and Pierre Robin for technical assistance and Danielle Chamereau for taking care of the animals. 


\section{REFERENCES}

Alexandrides, T., Moses, A. C. \& Smith, R. J. (1989). Developmental expression of receptors for insulin, insulin-like growth factor I (IGF-I), and IGF-II in rat skeletal muscle. Endocrinology 124, 1064-1076.

Beaudry, M. A., Chiasson, J. L. \& Exton, J. H. (1977). Gluconeogenesis in suckling rat. American Journal of Physiology 233, E175-E180.

Blazquez, E., Rubalcava, B., Montesano, R., Orci, L. \& Unger, R. H. (1976). Development of insulin and glucagon binding and the adenylate cyclase response in liver membranes of the prenatal, postnatal and adult rat: evidence of glucagon 'resistance'. Endocrinology 98, 1014-1023.

Chiasson, J. L., Liljenquist, J. E., Finger, F. E. \& Lacy, W. W. (1976). Differential sensitivity of glycogenolysis and gluconeogenesis to insulin infusions in dogs. Diabetes 25, 283-291.

Clarke, S. D., Armstrong, M. K. \& Jump, D. B. (1990). Dietary polyunsaturated fats uniquely suppress rat liver fatty acid synthase and S14 messenger RNA content. Journal of Nutrition 120, 225-231.

Coupé, C., Perdereau, D., Ferré, P., Hitier, Y., Narkewicz, M. \& Girard, J. (1990). Lipogenic enzyme activities and $\mathrm{mRNA}$ in rat adipose tissue during weaning: role of the diet. American Journal of Physiology 258, E126-E133.

Decaux, J. F., Ferré, P. \& Girard, J. (1986). Effect of weaning on different diet on hepatic gluconeogenesis in the rat. Biology of the Neonate 51, 331-336.

Ferré, P., Pégorier, J. P. \& Girard, J. (1977). The effects of inhibition of gluconeogenesis in suckling newborn rats. Biochemical Journal 162, 209-212.

Ferré, P., Turlan, P., \& Girard, J. (1985). Effects of medium chain triglyceride feeding or glucose infusion on glucose kinetics in the newborn rat. Journal of Developmental Physiology 7, 37-46.

Foufelle, F., Gouhot, B., Pégorier, J. P., Perdereau, D., Girard, J. \& Ferré, P. (1992). Glucose stimulation of lipogenic enzyme gene expression in cultural white adipose tissue. A role for glucose-6-phosphate. Journal of Biological Chemistry 267, 20543-20546.

Gandemer, G., Pascal, G. \& Durand, G. (1982). In vivo changes in the rates of total lipid and fatty acid synthesis in liver and white adipose tissues of male rats during post-weaning growth. International Journal of Biochemistry 14, 797-804.

Girard, J. R., Ferré, P., Kervran, A., Pégorier, J. P. \& Assan, R. (1977). In Glucagon: Its Role in Physiology and Clinical Medicine, pp. 563-581 [P. P. Foa, J. S. Bajaj and N. L. Foa, editors]. New York: Springer-Verlag.

Girard, J. R., Ferré, P., Pégorier, J. P. \& Duée, P. H. (1992). Adaptations of glucose and fatty acid metabolism during perinatal period and suckling-weaning transition. Physiological Reviews 72, 507-562.

Hahn, P. (1970). Fatty-acid synthesis in brown and white adipose tissue and liver of the rat during development. Physiological Bohemoslovaka 19, 369-373.

Henning, S. (1981). Postnatal development: coordination of feeding, digestion, and metabolism. American Journal of Physiology 241, G199-G214.

Issad, T., Coupé, C., Ferré, P. \& Girard, J. (1987). Insulin-resistance during suckling period in rats. American Journal of Physiology 253, E142-E148.

Issad, T., Coupé, C., Pastor-Anglada, M., Ferré, P. \& Girard, J. (1988). Development of insulin-sensitivity at weaning in the rat. Role of the nutritional transition. Biochemical Journal 251, 685-690.

Issad, T., Ferré, P., Pastor-Anglada, M., Baudon, M. A. \& Girard, J. (1989). Development of insulin sensitivity in white adipose tissue during the suckling-weaning transition in the rat: involvement of glucose transport and lipogenesis. Biochemical Journal 264, 217-222.

Leturque, A., Postic, C., Ferré, P. \& Girard, J. (1991). Nutritional regulation of glucose transporter in muscle and adipose tissue of weaned rats. American Journal of Physiology 260, E588-E593.

McCune, S. A. \& Harris, R. A. (1979). Mechanism responsible for 5-(tetradecyloxy)-2-furoic acid inhibition of hepatic lipogenesis. Journal of Biological Chemistry 254, 10095-10101.

Margolis, R. N., Tanner, K., Seminara, D. \& Taylor, S. (1990). Insulin receptors in developing rat liver. Receptor autophosphorylation and phosphorylation of the endogenous substrate pp120/HA4 (ectoATPase) in fetal and neonatal rat. Biology of the Neonate 58, 227-235.

Maury, J., Burnol, A. F., Loizeau, M., Issad, T., Girard, J. \& Ferré, P. (1992a) Insulin receptor function is preserved in a physiological state of hypoinsulinemia and insulin resistance. American Journal of Physiology 262, E818-E825.

Maury, J., Issad, T., Perdereau, D., Gouhot, B., Ferré, P. \& Girard, J. (1993). Effect of acarbose on glucose homeostasis, lipogenesis and lipogenic enzyme gene expression in adipose tissue of weaned rats. Diabetologia 36, 503-509. 
Maury, J., Kerbey, A. L., Girard, J. \& Ferré, P. (1992b). Nutritional regulation of pyruvate dehydrogenase expression in rat adipose tissue at weaning. Diabetologia 35, A167.

Perdereau, D., Foufelle, F., Gouhot, B., Ferré, P. \& Girard, J. (1992). Influence of diet on the development and regulation of lipogenic enzymes in adipose tissue. Proceedings of the Nutrition Society 51, 387-395.

Perdereau, D., Narkewicz, M. R., Coupé, C., Ferré, P. \& Girard, J. (1990). Hormonal regulation of specific gene expression during development in the rat. Advances in Enzyme Regulation 30, 91-108.

Sinha, M. K. \& Jenquin, M. (1987). Subunit structure, autophosphorylation, and tyrosine-specific protein kinase. Activity of hepatic insulin receptor in fetal, neonatal and adult rats. Diabetes 36, 1161-1166.

Snell, K. \& Walker, D. G. (1973). Gluconeogenesis in the newborn rat: the substrates and the quantitative significance. Enzyme 15, 40-81.

Tsujikawa, M. \& Kimura, S. (1980). Changes in lipid synthesis in rat adipose tissue during development. Journal of Nutritional Science and Vitaminology 26, 367-374.

Tsujikawa, M. \& Kimura, S. (1981). Effect of litter size on glucose metabolism in rat pup adipose tissue during the suckling period. Journal of Nutritional Science and Vitaminology 27, 361-366.

Wang, C. (1985). Insulin-stimulated glucose uptake in rat diaphragm during postnatal development: lack of correlation with the number of insulin receptors and of intracellular glucose transporters. Proceedings of the National Academy of Sciences USA 82, 3621-3625. 